\title{
Dinamika Aktor dalam Forum Komunikasi Tanggung Jawab Sosial Perusahaan di Kabupaten Tuban
}

\author{
Bedhah Adityo Nugroho ${ }^{1}$, Janianton Damanik ${ }^{2}$
}

\begin{abstract}
Abstrak
Keragaman aktor dalam forum komunikasi ternyata menimbulkan pergeseran karakter kelembagaan dan konstestasi kepentingan secara sengit. Tujuan studi ini adalah untuk menjelaskan dinamika hubungan dan interaksi antar-aktor di dalam kelembagaan pemangku kepentingan di Kabupaten Tuban. Metode kualitatif digunakan dengan bersandar pada sumber data dokumentasi/literatur, observasi, dan wawancara mendalam. Metode terakhir ini melibatkan 11 orang informan kunci yang merupakan representasi perusahaan, negara, dan masyarakat yang terlibat dalam kelembagaan (Forum Komunikasi CSR) FKCSR di Tuban. Hasil menunjukkan bahwa aktor utama sekaligus yang melahirkan FKCSR adalah negara sehingga menjadikan kelembagaannya bersifat instruktif (top down) dan state-centris. Pemerintah lokal mendominasi forum dan aktor lainnya melalui legitimasi peraturan daerah dan menciptakan ketergantungan aktor perusahaan pada negara. Terjadi juga pergeseran kekuasaan dari basis aturan ke basis kepentingan yang menimbulkan dilema institusi, serta disorientasi kelembagaan dan kontestasi sumberdaya antar aktor. Dinamika politis aktor dan institusi tersebut belum mencapai perbaikan optimal pada tata kelola CSR.
\end{abstract}

Kata kunci: aktor, corporate social responsibility, dinamika, institusionalisasi, pemangku kepentingan

\begin{abstract}
The divergent of actors within communicaton forum influence the changing of institution's characters and escalate the interest contestation. The objective of this study is elucidating the dynamic relations and interaction among actors under the authoritative organization in Tuban district. This article employed qualitative method which uses literatures, documentations, observations, and in-dept interviews. The latest method relies on eleven central informants that represent company, country, and society who have relation with CSR Communication Forum in Tuban. Th result shows that the main actor who initiate the emergence of CSR Communication Forum is country, thus affect the nature of institution which more instructive (top-down) and state-centric. The local government is dominating the forum and other actors use the local regulation to produce dependency of company to country. In addition, shifting of power from regulation based to interest based create institution dilemma, institution disorientation and competition of resources among actors. Although using CSR governance, the political dynamics and institution development have not achieved its optimum result.
\end{abstract}

Key words: actor, corporate social responsibility, dynamics, interest group, institutionalization

\section{Pendahuluan}

Tata kelola Corporate Social Responsibility (CSR) terus mengalami ragam pembaharuan dan kompleksitas, salah satunya menyangkut perihal kelembagaan. Forum CSR menjadi salah satu instrumen kelembagaan yang berhubungan dengan fungsi tata kelola yang mempertemukan pemangku kepentingan (Buhmann, 2011; Golob \& Podnar, 2014). Idealnya, forum ini juga mampu menjadi ruang konsesus dan kerjasama dalam tahapan formulasi dan implementasi CSR (Høvring, Andersen, \& Nielsen, 2018, p. 641). Namun, keberadaan Forum CSR di Kabupaten Tuban belum mampu menunjukkan kinerja yang optimal di tengah derasnya arus investasi berskala nasional dan internasional.

Dominasi peran negara telah menciderai amanat fasilitasi yang disematkan pada FKCSR. Aspirasi dan representasi masyarakat turut terabaikan. Keberadaan FKCSR lebih berkesan menggugurkan kewajiban dari pada institusiyang menyelesaikan masalah sosial, mengakomodasi kepentingan dan memperbaiki tata kelola CSR. Akibatnya, forum ini gagal mempertemukan aktor untuk berkolaborasi secara intensif. Ujungnya, kondisi ini mendangkalkan orientasi pembangunan sosial sebatas pada proyek infrastruktur dan bantuan karitatif.

\footnotetext{
${ }^{1}$ PT Semen Indonesia (Persero) Tbk (email korespodensi: bedhah.adityo@gmail.com) ${ }^{2}$ Departemen Pembangunan Sosial dan Kesejahteraan, Universitas Gadjah Mada (email; antondmk@ugm. ac.id)
} 
Studi ini bertujuan untuk memetakan dinamika aktor yang terjadi dalam Forum Komunikasi CSR di Kabupaten Tuban. Studi diawali dari pelacakan aspekgenealogis mengenai runutan historis dan konteks yang melatarbelakangi lahirnya FKCSR Tuban. Berikutnya, dilakukan pengamatan seksama pada aktor-aktor FKCSR untuk memahami dinamika aktor, meliputi: pola relasi, interaksi dan derajat kepentingan yang dikontestasi-kan. Identifikasi aktor atau dalam hal ini pemangku kepentingan menjadi kebutuhan yang mendasar untuk melihat watak dan arah pencapaian (goals) yang diharapkan (Crane \& Ruebottom, 2011; Mayers, 2005; Nishat, Rahman, Mandal, \& Mahmud, 2016). Selain aktor, analisa terhadap faktor-faktor krusial yang menghambat dan mendorong dinamika institusi menjadi fokus yang dikedepankan.

Studi ini juga memiliki tujuan untuk melihat sejauhmana kontribusi positif Forum Komunikasi CSR dalam memperbaiki tata kelola CSR perusahaan perusahaan di wilayah Kabupaten Tuban. Pemikiran ini didasarkan pada proyeksi optimis pada dimensi kelembagaan Forum Komunikasi CSR Tuban yang berpotensi terhadap pencapaian pembangunan daerah dan pemberdayaan masyarakat. Dalam pandangan yang lebih jauh, studi ini diharapkan mampu menjadi referensi praksis yang mengakselerasi perbaikan tata kelola CSR, baik di skala lokal maupun nasional.

\section{Kerangka Teori}

Studi ini memiliki dua fokus utama. Fokus yang pertama adalah mengidentifikasi aktor dalam FKCSR. Dalam kasus ini, terma aktor memiliki kesejajaran makna dengan terma pemangku kepentingan. Kesejajaran ini didasarkan pada kesamaan sifat dan nilai keduanya, yakni pada aspek: a) bersifat materiil, dalam wujud tunggal atau jamak; b) membawa kepentingan; c) menggunakan pengaruh; dan d) bekerja dialektis dalam struktur, serta e) berorientasi pada pencapaian tujuan. Sifat dan nilai tersebut bertransformasi menjadi karakter (identitas) masing-masing aktor (Friedman \& Miles, 2006; Mainardes, Alves, \& Raposo, 2011). Secara operasional, karakter menjadi pedo-man yang menuntun dalam proses pemilahan dan menganalisa maksud serta derajat kepentingan para aktor di pusaran FKCSR Kabupaten Tuban.

Setelah proses identifikasi aktor, dilanjutkan dengan pemetaan relasi, interaksi, dan dinamika antar aktor. Pemetaan ini dilakukan menggunakan dua pendekatan yang diajukan oleh Meyer (2010), yang menitik-beratkan pada dua hal. Pertama ialah aspek keseimbangan yang memuat: hak, tanggung jawab dan manfaat bersama yang dilakukan di aras inter ataupun antar aktor/pemangku kepentingan (Pope \& Meyer, 2015). Garis keseimbangan ini menjadi indikasi terhadap kekuatan, insentif, dan disinsentif terhadap pencapaian tujuan.

Kemudian kedua ialah aspek relasi antar aktor/pemangku kepentingan. Aspek ini berfungsi untuk melihat hubungan dan interaksi yang terjadi antar aktor/pemangku kepentingan sebagai modal untuk memahami konsensuskonsensus yang terjadi dalam pencapaian tujuan (Pope, Bromley, Lim, \& Meyer, 2018). Analisis berkaitan dengan relasi antar aktor/pemangku kepentingan terdiri dari:

a. Kualitas relasi sebagai indikasi terhadap posisi pihak yang berkepentingan berderajat baik, sedang, buruk atau berkonflik;

b. Kekuatan relasi, meliputi analisa terkait dengan frekuensi dan intensitas kontak;

c. Formalitas relasi, berkaitan dengan intervensi dan dominasi dalam relasi;

d. Ketergantungan antar pemangku kepentingan, merupakan analisis yang berkaitan dengan dengan derajat ketergantungan antar pihak yang berkepentingan dalam suatu relasi.

Fokus kedua, menitikberatkan perhatian pada relevansi FKCSR Tuban dengan pendekatan institusi. Prasyarat penting sebelum menggunakan pendekatan institusi ialah mengidentifikasi posisi FKCSR diantara ketiga dimensi perdebatan perihal genealogi pemikiran CSR (Susetiawan, 2012). Dimensi pertama menempatkan pemahaman CSR yang lahir dari rahim korporasi (perusahaan) sebagai kesadaran etis atas degradasi lingkungan dan kesenjangan ekonomi yang ditimbulkan. Sementara itu dimensi yang kedua melihat bahwa CSR dilakukan adalah akibat desakan tuntutan dan dorongan dari berbagai aktor yang terpapar dampak langsung maupun tidak. Dimensi ketiga lebih melihat CSR sebagai instrumen mencapai idealitas konstelasi sosial dan kesejahteraan masyarakat melalui kerjasama antarpihak berkepentingan.

Identifikasi posisi yang dilakukan memiliki kontribusi yang besar pada proses 
memahami karakter (corak/pola) institusi dan cara bekerjanya institusinya. Argumen ini dibangun dari asumsi dasar bahwa karakter dari sebuah FKCSR selalu lahir dari alam pemikiran (konseptual) yang sistematis dan konsisten. Ketika proses identifikasi terkait posisi genealogis berhasil dilampaui, maka FKCSR Tuban baru dapat ditelusuri lebih seksama dengan pendekatan institusi (Carstensen \& Schmidt, 2016; Hwang \& Colyvas, 2011). Pendekatan ini memainkan peranan penting dalam proses mengidentifikasi sepak terjang dan latar belakang masing-masing aktor di suatu arena kepentingan. Jalan berpikir ini sepaham dengan pemikiran Goodin (1996) bahwa institusi menjadi alat bantu untuk memahami suatu pola perilaku yang berulang dan stabil. Institusi dengan serangkaian nilai, prinsip dan norma mampu menjadi batas kendali terhadap besarnya hasrat aktor (pemangku kepentingan) untuk monopoli sumberdaya dan maksimalisasi keuntungan dalam ranah CSR.

Selain menganalisis dinamika aktor dalam FKCSR, kajian ini berupaya memperkaya pengetahuan perihal institusi dari sisi informal. Upaya ini sejalan dengan gagasan Marsh \& Stoker (2002, p. 18) yang meletakkan institusi pada ranah praksis (epistemologi) yang memuat: nilai dan hubungan kekuasaan; peluang dan rintangan desain institusional, serta perlu menjangkau dimensi informal kehidupan. Upaya menggali sisi informal dari sebuah institusi penting untuk dilakukan sebagai kritik terhadap kuatnya dominasi perspektif formal-normatif dan elitisme dalam pemikiran institusi (Đurić, 2011). Pemikiran perihal institusi dari FKCSR juga perlu dilengkapi dengan cara menjawab pertanyaan kritis yang diajukan oleh Marsh dan Olsen (1984) tentang: apa yang menyusun institusi politik, bagaimana mereka bisa menentukan dan mempertahankan kepenti-ngan (tentang cara bekerja sebuah institusi), dan bagaimana kemampuan aktor individu mempengaruhi bentuk dan berfungsinya institusi politik yang relatif otonom? (Carrigan \& Coglianese, 2011; Ohanyan, 2012; Radaelli, Dente, \& Dossi, 2012) Beberapa pertanyaan yang diajukan ini konsisten dengan asumsi bahwa FKCSR senantiasa menjadi arena pertukaran kepentingan dan konsensus antar aktor baik sifatnya formal maupun informal. Asumsi ini dapat dijelaskan dengan menggunakan dua model diantara tujuh model/cabang institusi baru yang diajukan oleh Peters (2019).
Pertama, institusionalis pilihan rasional yang menjelaskan bahwa institusi politik (FKCSR) merupakan sistem aturan dan desakan yang di dalamnya individu atau kelompok berusaha untuk memaksimalkan kegunaan mereka. FKCSR sebagai institusi politik mempengaruhi perilaku dan mempengaruhi "struktur dari situasi" ketika individu memilih strategi untuk mengejar preferensi (Aligica \& Boettke, 2011; Ostrom, 1982). Pemahaman ini menawarkan fungsi dari institusi perihal ketersediaan informasi, prognosis perilaku perilaku, dan kalkulasi dorongan dan hambatan pada dinamika tindakan. Selebihnya, model ini meyakini bahwa institusi merupakan buatan manusia yang bermanfaat, dirancang untuk memecahkan persoalan tindakan kolektif (Đurić, 2011; Marsh \& Stoker, 2002, p. 112). Model ini memandu dalam pencarian preferensi aktor baik yang bersifat individu maupun kelompok di Tuban saat mereka berelasi, berinteraksi dan berdinamika di FKCSR. Hal ini menjadi fungsi tambahan untuk melihat perspektif stok sumberdaya dan pertukarannya serta orientasi tujuan masing-masing aktor dalam FKCSR.

Kedua, institusionalis jaringan yang menunjukkan bagaimana pola-pola interaksi yang diatur kerapkali bersifat informal antara individu dan kelompok dapat membentuk perilaku politik. Nilai dan tujuan menjadi simpul penjamin stabilitas jaringan. Marsh dan Rhodes (1992, p. 96) menambahkan bahwa simpul adalah konsensus yang merupakan produk/formulasi dari proses renegoisasi terus menerus oleh aktor dengan berbagai kapasitas kekuasaan. Bertalian dengan model sebelumnya, tindakan rasional berkontribusi terhadap format institusi secara dinamis (Caballero \& Soto-Oñate, 2015, pp. 958-959). Model ini berfungsi untuk melihat signfikansi dan eksistensi institusi (FKCSR), artinya ketika interaksi aktor berpola menembus sekat organisasial maka terdapat nilai dan tujuan serta konsensus yang sedang diperjuangkan. Hadirnya konsensus dan stabilitas jaringan dalam model ini menjadi titik ekuilibirium (komprosmistis) terhadap justifikasi informalitas FKCSR.

\section{Metode}

Kajian mengenai Forum Komunikasi CSR (FKCSR) di Kabupaten Tuban ini diuraikan secara komprehensif melalui beberapa dimensi, yakni: 1) Dimensi institusional forum CSR; 
2). Dimensi dinamika aktor dalam forum CSR, dan 3). Dimensi kontribusi forum CSR dalam tata kelola CSR. Berdasar pada ketiga dimensi tersebut, pendekatan aktor pemangku kepentingan dalam konteks institusional (FKCSR) digali melalui metode kualitatif dengan pendekatan studi kasus. Langkah ini sesuai dengan gagasan Perreault dan Mc.Carthy (2006, p. 176) bahwa penelitian kualitatif mampu menggali informasi secara mendalam, serta terbuka terhadap segala pendapat dan pernyataan, tidak semata pada jawaban "ya' dan "tidak". Dalam konteks ini, pelacakan sisi-sisi kelembagaan FKCSR dan identifikasi aktor yang ada di dalamnya menggunakan jalan berpikir penelitian kualitatif. Artinya, FKCSR tidak semata dilihat sebagai sebuah institusi dari sisi eksistensinya, namun lebih jauh berdiskusi soal komponen-komponen apa yang menyusunnya, serta bagaimana komponen saling terhubung satu sama lain.

Proses meneliti dilakukan dengan sejumlah teknik dalam mengumpulkan data. Pertama, peneliti melakukan studi terhadap literatur dan pemetaan regulasi yang sesuai dengankajian FKCSR. Beberapa aturan yang dipetakan dan menjadi rujukan adalah: a) Peraturan Menteri Sosial No. 13 Tahun 2012 tentang Forum Tanggung Jawab Sosial Dunia Usaha dalam Penyelenggaraan Kesejahteraan Sosial; b) Peraturan Menteri Sosial No. 6 Tahun 2016 tentang Tanggung Jawab Sosial Badan Usaha dalam Penyelenggaraan Kesejahteraan Sosial; c) Surat Keputusan Menteri Sosial Republik Indonesia No. 185/HUK/2016 tanggal Mei 2016 tentang Forum Tanggung Jawab Sosial Badan Usaha dalam Penyelenggaraaan Kesejahteraan Sosial; d) Peraturan Daerah Provinsi Jawa Timur No. 4 Tahun 2011 tentang Tanggung Jawab Sosial Perusahaan; e) Peraturan Gubernur No. 52 Tahun 2012 tentang Pelaksanaan Peraturan Daerah Provinsi Jawa Timur No. 4 Tahun 2011 tentang Tanggung Jawab Sosial Perusahaan (TSP); f) Peraturan Daerah No. 3 Tahun 2015 tentang Tanggung Jawab Sosial Perusahaan (TSP).

Selain membaca regulasi dengan seksama, peneliti juga menelaah sejumlah studi yang dilakukan peneliti sebelumnya tentang CSR di Kabupaten Tuban (Yaskun dan Cahyono, 2016; Ariefianto, 2016; Rochayatun, Handayati, dan Gunartin, 2016) dan LSM FITRA JATIM yang didukung oleh TIFA Foundation. Proses penggalian data secara tekstual juga dilakukan dengan pembacaan terhadap naskah-naskah notulensi rapat yang terhimpun di Sekretariat FKCSR Tuban periode tahun 2016 hingga 2017. Peneliti juga menggali informasi dari kumpulan pemberitaan yang bersumber dari publikasi media lokal, yang rata-rata berupa media daring (online, yakni: a) Radar Tuban; b) Bangsa Online; c) Suara Banyuurip.com; dan d) Kabartuban.com. Media lokal ini merupakan saluran informasi utama dan terkini di wilayah Tuban dan sekitarnya. Teknik penggalian data berikutnya ialah menggunakan wawancara mendalam. Terdapat beberapa informan yang berhasil diwawancarai secara mendalam pada tahapan ini, yakni: a) WD, ex officio, Ketua FKCSR Tuban periode tahun 2015-2016 sekaligus Kepala Biro Humas dan CSR PT Semen Indonesia (Persero) Tbk-Pabrik Tuban; b) HK, Kepala Seksi Bina Lingkungan PT Semen Indonesia (Persero) Tbk-Pabrik Tuban periode 2015-2016; c). AS, Kepala Departemen Komunikasi dan Sarana Umum PT Semen Indonesia (Persero) TbkPabrik Tuban periode 2016-2018; d). WE, Kepala Seksi Bina Lingkungan PT Semen Indonesia (Persero) Tbk-Pabrik Tuban periode 20162017, dan e). YA, administrator di Sekretariat FKCSR Tuban.

Selain itu peneliti juga menemui menemui beberapa informan berikutnya dari kalangan birokrat dan legislator di Kabupaten Tuban untuk menggali data dan informasi perihal proses perumusan Perda CSR dan FKCSR Tuban serta relasi dan interaksi antara pemerintah dan korporasi. Informan yang bersedia menemui peneliti dan memberikan sejumlah informasi dan data yakni: a). AI, Kepala Bidang Perekonomian BAPPEDA Kabupaten Tuban; b). Kt, mantan Ketua DPRD Tuban dan masih menjadi Anggota DPRD Tuban; c). SN, anggota DPRD Tuban Periode 2014-2019 dari Komisi C.

Terakhir, tahapan wawancara mendalam dilakukan peneliti dengan pihak yang berkepentingan di luar struktur keanggotaan FKCSR. Hal ini penting dilakukan untuk melihat sejauhmanana keterlibatan aktor-aktor berkepentingan dalam perumusan Perda dan FKCSR. Berikutnya soal relasi dan interaksi aktorkelompok kepentingan terhadap pemeritah dan korporasi, serta proyeksi dan ekspektasi terhadap hadirnya FKCSR di Tuban. Beberapa informan yang merepresentasikan kalangan masyarakat sipil ialah: a) NF, Direktur Koalisi 
Perempuan Ronggolawe (KPR), yang merupakan lembaga swadaya masyarakat bereksistensi kuat di Tuban; b) AAM, seorang kontributor Radar Tuban; c) GW, redaktur media daring lokal Bangsa Online. Pertemuan ini memberikan banyak temuan menarik soal terbatasnya akses masyarakat pada diskursus dan praksis CSR. Mereka juga mengonfirmasi lemahnya tata kelola yang memadai soal pelaksanaan CSR di wilayah Kabupaten Tuban. Informasi yang berhasil dihimpun ini selanjutnya diolah menjadi data yang menopang argument dan memberikan pemahaman sesuai dengan rumusan masalah. Selain itu juga dilakukan kompilasi catatan informasi dan data baik dari informan maupun data sekunder yang dirumuskan dalam catatan lapangan. Data dan informasi tersebut selanjutnya diklasifikasilan secara manual dengan memberi label pada setiap kategori.

Ada tiga kategori data yang sesuai dengan klasifikasi tersebut, yakni:

a. Struktur dan anggota FKCSR yang datadata yang diberi warna merah. Data-data ini dipilah kembali bedasarkan aspek: inisiasi, kinerja forum, proses kebijakan dan pengambilan keputusan, pemetaan aktor serta jaring interaksinya, dan perspektif masing-masing aktor dalam forum.

b. Pembuat dan pelaksana kebijakan CSR di Tuban yang datanya diberi warna hijau dan kemudian dipilah berdasarkan proses perumusan Perda dan Forum CSR dan relasi serta interaksi antara pihak pemerintah dengan korporasi dan masyarakat.

c. Kelompok kepentingan di Tuban yang datanya diberi label warna biru dan dianalisis berdasarkan pemahaman terhadap forum CSR, keterlibatan dalam forum, relasi dan interaksi antara kelompok kepentingan dengan forum, korporasi dan pemerintah, serta proyeksi dan ekspektasi keberadaan Forum Komunikasi CSR.

Proses analisis untuk memetakan dinamika aktor dilakukan dengan beberapa tahapan. Awalnya, peneliti mengidentifikasi aktor yang aktif dalam FKCSR. Keaktifan ini dilihat dari sejauhmana intensitas relasi yang didapatkan dari presensi masing-masing aktor dalam aktivitas FKCSR. Keaktifan aktor juga dilihat dari kontribusi gagasan dan program yang dilaksanakan dalam konteks FKCSR. Kontribusi aktor dalam FKCSR dapat diidentifikasi salah satunya melalui dokumen Notulensi Rapat Koordinasi Forum Pelaksana Tanggungjawab Sosial Perusahaan Kabupaten Tuban, tanggal 9 Agustus 2016. Sumber informasi berikutnya yang dijadikan basis justifikasi ke-aktor-an ialah: konten pemberitaan media massa di Tuban dalam kurun waktu 2015 hingga 2017 dan beberapa pernyataan dari aktor kunci.

Sejumlah aktor yang berhasil teridentifikasi dari presensi dan kontribusi ini divalidasi lebih dalam aspek-aspek keaktorannya. Validasi ini menggunakan koridor konseptual mengenai aktor yang menekankan bahwa: aktor dipahami sebagai individu, kelompok maupun organisasi yang memiliki daya pengaruh -mempengaruhi struktur atau kebijakan- berdasar pada sumbersumber kuasa yang dimiliki. Aktor secara lebih rinci diposisikan sebagai individu yang memiliki beberapa ukuran kekuasaan atau otoritas dalam suatu masyarakat, ia memiliki signifikansi pengaruh pada keputusan, kebijakan, pemberitaan media, dan diasosiasikan pada dampak konflik.

Selanjutnya informasi dari aktor ini dikelompokkan menurut konfigurasi politiknya dengan menggunakan cara berpikir "arena politik" (Linz \& Stepan, 1996). Arena politik ialah ruang yang tersusun dari konfigurasi empat aktor utama, yakni: negara, partai politik, perusahaan, dan LSM/Ormas (Zuhro, 2009, p. 22). Kategorisasi ini juga dilengkapi dengan pembacaan pada aspek: kepentingan dan basis kuasa yang dimiliki aktor dengan batasan pada isu FKCSR.

Pemetaan dinamika aktor dilakukan dengan analisis yang mendalam berkaitan pada aspek: kontestasi kepentingan; perebutan sumberdaya; dan pengaruh yang ada dalam isu FKCSR. Ketiga aspek ini dilihat dari basis informasi yang berada pada ranah gagasan (ide) dan praksis yang berlangsung pada ruang formal maupun informal. Pengelolaan data dan analisis pada ranah gagasan gagasan (ide) berpijak pada pembacaan wacana yang ada pada: pernyataan di aturan (perda, SK, perbup), pemberitaan media massa lokal di Tuban, data statistik resmi maupun pernyataan langsung dari informan. Di sisi lain, untuk memahami ranah praksis, peneliti melakukan olah data dan analisis berpijak pada kasus-kasus yang terjadi dalam lingkup FKCSR Tuban, dengan sumber data: pernyataan informan, data statistik dan pemberitaan media 
massa lokal di Tuban. Pemetaan dinamika aktor sesungguhnya merupakan penggambaran dari perubahan kondisi pada tataran ide maupun praksis yang terjadi akibat adanya interaksi dan interdependensi antar individu yang terjadi secara timbal balik dan berkesinambungan. Perubahan yang dimak-sud merupakan ekspresi dari kekuatan, pergerakan, perkembangan dan adaptasi terhadap keadaan (Zulkarnain, 2013, p. 35).

Konsisten dengan pendekatan studi kasus, kajian dinamika aktor ini berpijak pada batasan institusi sebagai sistem yang terikat sebagai basis ekplorasi dan interpretasi. Sistem terikat ini menjadi "kasus" yang terikat oleh waktu dan tempat (Creswell, 2007, p. 36). Berkenaan dengan hal tersebut, maka sistem terikat yang dimaksud dalam kajian ini ialah institusi FKCSR di Kabupaten Tuban dengan rentang waktu mulai tahun 2016 hingga 2017.

\section{Hasil dan Diskusi}

\section{Dimensi Institusional FKCSR Tuban}

FKCSR dapat digolongkan sebagai institusi politik oleh karena terdapat relasi kuasa antar aktor berkepentingan dan kontestasi kemampuan aktor untuk saling mempengaruhi bentuk dan berfungsinya sebuah institusi. Dalam konteks ini, ditunjukkan dengan peran sentral negara (Pemkab) dalam memonopoli FKCSR melalui aturan dan arahan. Lebih tepatnya. Institusi politik ini sepemahaman dengan pendekatan institusi baru (new institutionalism), karena seperangkat aturan bekerja lebih mendominasi ketimbang organisasi politik, dalam menuntun dan membatasi perilaku aktor individu (Carrigan \& Coglianese, 2011; Peters, 2019). Keberadaan aturan lebih penting dan efektif ketimbang organisasi mengingat kemampuan dalam memberikan informasi dan memberikan sanksi atas ketidakpatuhan di masa mendatang.

Aksi dominasi aktor negara (Pemkab Tuban) di dalam institusi menggunakan perangkataturan dan monopoli wacana dapat digolongkan sebagai fenomena isomorphis (kesamaan). Coercive isomorphis terjadi ketika suatu organisasi terbentuk oleh karena respon yang sama terhadap organisasi lain disebabkan oleh tekanan-tekanan negara (Othman, Darus, \& Arshad, 2011). Tekanan dalam konteks ini ialah keterpaksaan melakukan adopsi aturan atau struktur yang lebih tinggi (aturan
Pemerintah Pusat dan Provinsi). Fenomena ini cukup memberikan jawaban atas ketiadaan pelibatan unsur masyarakat dan perusahaan saat perumusan Perda CSR. Kendatipun FKCSR Tuban berhasil dijustifikasi sebagai sebuah institusi politik, namun beberapa hal perlu didiskusikan lebih lanjut. Sepanjang analisis kronologi dan praksis, narasi lebih menokohkan aktor negara pada peran mendominasi dengan watak instruktifnya (top-down).

\section{Dinamika Aktor dalam FKCSR}

Praktik yang terjadi menunjukkan secara gamblang bahwa Pemkab Tuban melakukan aksi "koersif", senalar dengan wacana retoris yang dibuat. Bappeda dan Dinas (OPD) sebagai kaki tangan Bupati secara terang-terangan mengarahkan perusahaan untuk mengeksekusi program yang ditetapkan secara sepihak. Momentum pertemuan antara Pemkab dan perusahaan dalam FK CSR, berujung pada pembebanan perusahaan untuk mengeksekusi lima program pembangunan dalam isu pengentasan kemiskinan, yakni: 1). Jambanisasi; 2). Pembangunan RTLH; 3). Perbaikan Sanitasi; 4). Pipanisasi Air Bersih; dan 4). Pem-bangunan Depo Sampah. Kasus ini memberikan isyarat bahwa negara senantiasa berupaya mendominasi aktor dan ruang melalui instrumen-instrumen pemaksa.

Kelembagaan yang sebelumnya digagas bebas nilai politik telah bergeser menjadi arena politik yang dinamis. Sepanjang penelitian teridentifikasi hanya sejumlah aktor yang berkepentingan dan mendominasi di FKCSR Tuban (FK CSR) dibandingkan keikutsertaan 15 OPD (Organsasi Perangkat Daerah) dan 33 dari unsur pimpinan perusahaan. Selain aktor yang berada dalam struktur FK CSR eksisting, senyatanya terdapat aktor dari elemen masyarakat sipil (civil society) yang berkepentingan terhadap FK CSR. Malangnya, mereka tidak memiliki akses informasi dan jejaring yang memadai untuk duduk dalam forum tersebut. Aktor yang berhasil teridentifikasi ini dilacak melalui kehadiran dan kontribusi gagasan yang terdokumentasikan dalam naskah notulensi rapat yang dikelola oleh Sekretariat FKCSR. Selain itu, munculnya aktor-aktor ini ke permukaan juga dikarenakan intensitas berjejaring baik secara formal maupun informal. Keaktifan dalam rapat dan kontri-busi gagasan sejatinya. 
Konsekuensi pergeseran FKCSR menjadi arena politik, bukan hanya disebabkan hadirnya empat aktor dan reproduksi wacana, namun juga berkaitan dengan perebutan sumberdaya (resource). Tepatnya, perebutan akses terhadap sumberdaya CSR di Kabupaten Tuban. Pemahaman sumberdaya dalam konteks ini bukan dalam arti eksplisit seperti; air, emas, minyak, lahan, hutan, dan lain sebagainya. Namun lebih menekankan pada nilai intrinsiknya, yakni sebagai alat untuk mengendalikan dan menguatkan posisi tawar antar aktor (bargaining power). Hal ini tidak dapat dilepaskan dari esensi sumberdaya yang mengandung nilai-nilai kegunaan (usefullness) pada aspek ekonomi dan politik. Sumber daya CSR begitu besar dan bernilai strategis, tenyata menyimpan keterbatasan.

Kondisi tersebut berimbas pada terbukanya pertarungan (kontestasi) aktor dan watak saling mendominasi satu sama lain. Kontestasi dan dominasi atas pengendalian arena politik dalam pemahaman ruang, maupun subyek-subyek yang ada di dalamnya (aktor). Beberapa kasus yang berhasil sepanjang penelitian ini, menjadi fakta obyektif adanya praktik kontestasi dan dominasi tersebut, dintaranya: 1). Kasus pembentukan sepihak Forum CSR oleh Pemerintah Kabupaten Tuban; 2). Kasus penunjukkan langsung struktur FKCSR Tuban oleh Pemerintah Kabupaten Tuban; 3). Kasus Bupati yang mengarahkan perusahaan harus bertanggungjawan terhadap pengentasan kemiskinan; 4). Kasus resistensi perusahaan terhadap arahan Pemerintahan Kabupaten Tuban dalam FKCSR; 5). Kasus tumbuhnya forum-forum multipihak berskala lokal di sekitar perusahaan; 6). Kasus penyalahgunaan kewenangan pengawasan DPRD terhadap perusahaan dalam urusan CSR, dan 7). Kasus pengabaian aktor msyarakat dalam FKCSR Tuban.

\section{Kontribusi FKCSR terhadap Tata Kelola CSR di Tuban}

Kontribusi FKCSR terhadap perbaikan tata kelola CSR di Tuban masih berada dalam kadar yang minimal. FKCSR sejauh ini hanya sebatas memainkan peran dan fungsi yang bersifat normatif dan insidental. Artinya, institusi FKCSR belum mampu mewujudkan visi kelembagaan yang selaras dengan prinsip-prinsip tata kelola (governance), yakni: transparansi; akuntabilitas, responsibilitas, independensi dan kesetaraan serta kewajaran. Justru, kontribusi nyata perbaikan tata kelola CSR di Tuban lebih didorong oleh kesadaran perusahaan dalam melaksanakan aturan Pemerintah Pusat seperti: a) Undang-undang nomor 40 tahun 2007 tentang Perseroan Terbatas; b) Peraturan Menteri BUMN tentang PKBL tahun 2017 (PER-02-MBU-7-2017); c) Peraturan Menteri Lingkungan Hidup nomor 5 tahun 2011 tentang PROPER, ketimbang hasil rumusan/kesepakatan dalam lembaga FKCSR.

Kontribusi FKCSR Tuban terhadap perbaikan tata kelola dapat dijustifikasi minimalis ketika dikomparasikan dengan kinerja forum CSR di daerah lain. Di DKI Jakarta, forum csr memiliki visi dan orientasi kelembagaan yang jelas dan sistematis. Hal ini dapat dilihat dari kepemilikan program yang spesifik seperti: fasilitasi generasi milenial untuk menjalankan usaha di bidang kepedulian sosial, kesehatan, infrastruktur, dan lainnya (Indopos, 19/09). Dalam era sebelumnya, dana CSR yang dikelola forum CSR diarahkan untuk pembangunan rumah susun sewa dan RPTRA (ruang publik terbuka ramah anak) (Republika, 22/05/2016). Di samping program yang disesuaikan dengan kebutuhan, forum CSR DKI Jakarta juga memiliki roadmap dan sistem pengukuran kinerja (KPI) (Indopos, 19/09).

\section{Disorientasi Institusi FKCSR Tuban dan Ancaman Korporatisme Negara}

Independensi institusi FKCSR berhadapan langsung dengan dominasi negara yang kuat melalui konstruksi wacana dan aturan. Konteks ini, menunjukkan pemerintah berperan hiperaktif melampaui aturan yang dibuat sendiri. Perilaku hiperaktif ini merupakan ekspresi kuatnya hasrat untuk menguasai nilai dan sumber daya dalam CSR. Meminjam istilah yang tenar dalam kajian rezim orde baru, negara dalam konteks kajian ini telah mengidap sindrom korporatisme (state corporatism). Pratikno (1998) menjelaskan korporatisme negara sebagai penunggalan kelompokkelompok profesi dan kepentingan dalam kontrol penuh negara dengan alih-alih jaminan partisipasi dan artikulasi. Pada kondisi tersebut sebetulnya partisipasi masyarakat dibatasi dan hak kebebasan politiknya tercerabut. Kronologi dan suasana FKCSR Tuban saat ini juga sedang berada dalam ancaman korporatisme 
negara. Di masa Orde Baru, korporatisme berhasil menciptakan kepatuhan, stabilitas dan dukungan rezim. Sebaliknya, kajian ini menunjukkan praktik korporatisme justru menimbulkan resistensi, informalitas dan pengabaian integritas rezim pemerintahan sepaham dengan konsep institusionalis pilihan rasional dan institusionalis jaringan.

Prognosis dari praktik korporatisme negara dalam FKCSR Tuban ini ialah klientilisme CSR melalui institusi dan negara rawan terpapar virus klientilisme ini. Klientilisme digambarkan sebagai strategi rezim untuk mengakumulasi legitimasi dan sumberdaya melalui upaya-upaya "negara-isasi" sumber daya ekonomi, transaksi politik (money politic) dan sentralisasi aset hasil monopoli sumberdaya pada satu poros aktor (Hicken, 2011; Puskarina, Asiah, \& Madung, 2015). Prognosis ini akan menjadi realitas mendatang ketika posisi aktor dan dinamika yang terjadi dalam FKCSR Tuban mengalami stagnansi.

\section{Kesimpulan}

Studi ini menunjukkan kuatnya dominasi negara dalam dinamika kelembagaan FKCSR Tuban sehingga relasi dan interaksi antar aktor tidak setara, kontestatatf dan meniadakan representasi masyarakat. Dari perspektif kelembagaan, FKCSR belum dapat mempertemukan kepentingan aktor dan merumuskan orientasi kelembagaan multipihak. Alhasil, performa kelembagaan FKCSR menjadi minimalis dalam memperbaiki tata kelola CSR di Kabupaten Tuban. Secara rinci artikel ini kemudian menyimpulkan beberapa intisari.

Pertama, FKCSR Tuban merupakan institusi yang dihadirkan oleh pemerintah (state) melalui Perda nomor 3 tahun 2015 tentang TSP. Hal ini menjadikan karakter kelembagaan FKCSR bersifat instruktif (topdown), ditandai dari kuatnya arahan program, pengelolaan institusi sepihak dan meniadakan representasi masyarakat. Dominasi negara semakin menguat ketika perusahaan melegitimasi sanksi aturan dan hambatan prosedur perpanjangan ijin usaha.

Kedua, dinamika aktor terjadi saat institusi bergeser menjadi arena politik, dan bergesernya basis kuasa dari aspek aturan (rule) ke aspek kepentingan (interest). Bermula dari ulah negara mengonstruksi wacana pengentasan kemiskinan dan ketidaktercapaian formulasi kepentingan para aktor dalam FKCSR. Selain itu, dinamika aktor juga disebabkan oleh dilematika institusi, yakni di satu sisi, institusi harus menuntaskan misi mengelola beragam kepentingan aktor, namun negara terlalu kuat mengintervensi institusi FKCSR.

Ketiga, dinamika institusi disebabkan perubahan orientasi kelembagaan yang berkarakter top down dan kontestatif. Monopoli wacana dan ruang institusi oleh negara ternyata menimbulkan efek domino pada relasi dan interaksi aktor lainnya. Para aktor bersaing mempengaruhi fungsi dan menguasai sumberdaya institusi, serta wacana CSR di Kabupaten Tuban. FKCSR sebagai institusi mengandung nilai intrinsik yang besar, meliputi nilai ekonomis dan nilai politis. Penguasaan sumber daya ini berlangsung melalui konstruksi wacana dan optimalisasi basis kuasa yang terjadi di ruang formal, berpayung pada legalitas Perda TSP Tuban. Konstelasi ini menyebabakan keter-purukan orientasi kelembagaan dan menurunkan kinerja menata kelola CSR.

Keempat, kuatnya dominasi negara dalam FKCSR menimbulkan resistensi dan pragmatisme dari aktor perusahaan (economic society); aktor DPRD/politisi; dan aktor masyarakat sipil (civil society). Hal ini mempertajam konsep Rhodes (1999) tentang "intitusionalis jaringan" yang menekankan bahwa jika pola interaksi aktor menembus sekat organisasional maka ada nilai, tujuan dan konsensus yang diperjuangkan. Jadi, resistensi aktor ini dapat dimaknai sebagai tindakan rasional untuk lepas dari jerat aturan dan upaya memformulasi institusi untuk meraih pengakuan eksistensi nilai dan kepentingan.

Kelima, institusi FKCSR belum berkontribusi optimal bagi perbaikan tata kelola CSR di Tuban. Hal ini dapat diukur dari ketidakmampuan institusi dalam mencapai visi kelembagaan yang sesuai dengan prinsipprinsip tata kelola (governance), meliputi aspek: transparansi; akuntabilitas, responsibi-litas, independensi dan kesetaraan serta kewajaran yang telah diuraikan dalam bagian sebelumnya. Tata kelola perusahaan saat ini, lebih termotivasi oleh pelaksanaan aturan pemerintah pusat dan pemenuhan tuntutan masyarakat di sekitar perusahaan, ketimbang perda atau hasil rumusan/kesepakatan FKCSR. Selain itu, minimalisme kontribusi tersebut juga dapat dijustifikasi dari komparasi kinerja, visi dan orientasi kelem-bagaan antara FKCSR Tuban dengan Forum CSR DKI Jakarta. Terlebih lagi, 
posisi ketua Forum CSR DKI Jakarta berlatar belakang profesional, baik dari sisi profesi dan akademisnya sehingga mampu memacu hadirnya perbaikan-perbaikan tata kelola CSR.

\section{Acknowledgement}

Artikel ini merupakan hasil penulisan ringkas tesis penulis yang telah diuji dan dinyatakan lulus untuk meraih gelas Master of Arts dari Departemen Pembangunan Sosial dan Kesejahteraan (PSdK), Fakultas Ilmu Sosial dan Ilmu Politik, Universitas Gadjah Mada pada tahun 2018.

\section{Referensi}

Aligica, P. D., \& Boettke, P. (2011). Institutional Design and Ideas-Driven Social Change: Notes From an Ostromian Perspective. The Good Society, 20(1), 50-66.

Buhmann, K. (2011). Balancing Power Interests in Reflexive Law Public-Private CSR Schemes: The Global Compact and the EU's Multi-Stakeholder Forum on CSR. In K. Buhmann, L. Roseberry, \& M. Morsing (Eds.), Corporate Social and Human Rights Responsibilities (pp. 77-107). London: Palgrave Macmillan.

Caballero, G., \& Soto-Oñate, D. (2015). The Diversity and Rapprochement of Theories of Institutional Change: Original Institutionalism and New Institutional Economics. Journal of Economic Issues, 49(4), 947-977.

Carrigan, C., \& Coglianese, C. (2011). The Politics of Regulation: From New Institutionalism to New Governance. Annual Review of Political Science, 14, 107-129.

Carstensen, M. B., \& Schmidt, V. A. (2016). Power through, over and in ideas: conceptualizing ideational power in discursive institutionalism. Journal of European Public Policy, 23(3), 318-337.

Crane, A., \& Ruebottom, T. (2011). Stakeholder Theory and Social Identity: Rethinking Stakeholder Identification. Journal of Business Ethics, 102, 77-87.

Creswell, J. W. (2007). Qualitative inquiry and research design: Choosing among five approaches. Thousand Oaks: SAGE Publications.

Đurić, I. (2011). The New Institutionalism(s): A Framework for the Study of Public Policy in Post-conflict and Post-communist
Countries. Politička Misao, XLVIII(05), 85-105.

Friedman, A. L., \& Miles, S. (2006). Stakeholders: Theory and Practice. Oxford University Press.

Golob, U., \& Podnar, K. (2014). Critical points of CSR-related stakeholder dialogue in practice. Business Ethics: A European Review, 23(3), 248-257.

Goodin, R. E. (1996). The Theory of Institutional Design. Cambridge: Cambridge University Press.

Hicken, A. (2011). Clientelism. Annual Review of Political Science, 14, 289-310.

Høvring, C. M., Andersen, S. E., \& Nielsen, A. E. (2018). Discursive Tensions in CSR Multistakeholder Dialogue: A Foucauldian Perspective. Journal of Business Ethics, 152, 627-645.

Hwang, H., \& Colyvas, J. A. (2011). Problematizing Actors and Institutions in Institutional Work. Journal of Management Inquiry, 20(1), 62-66.

Linz, J. J., \& Stepan, A. C. (1996). Toward Consolidated Democracies. Journal of Democracy, 7(2), 14-33.

Mainardes, E. W., Alves, H., \& Raposo, M. (2011). Stakeholder theory: issues to resolve. Management Decision, 49(2), 226-252.

Marsh, D., \& Rhodes, R. A. W. (Eds.). (1992). Policy Networks in British Government. Oxford: Oxford University Press.

Marsh, D., \& Stoker, G. (Eds.). (2002). Theories and methods in political science. 2nd edition. Basingstoke: Palgrave Macmillan.

Mayers, J. (2005). Stakeholder Power Analysis. London: International Institute for Environemtent and Development.

Meyer, J. W. (2010). World Society, Institutional Theories, and the Actor. Annual Review of Sociology, 36, 1-20.

Nishat, B., Rahman, A. J. M. Z., Mandal, S., \& Mahmud, S. (2016). Stakeholder Analysis and Engagement Plan for Sundarban Joint Management Platform. International Water Association.

Nugroho, B. A., \& Damanik, J., (2018) Dinamika Aktor dalam Forum Komunikasi CSR di Kabupaten Tuban. Tesis, Universitas Gadjah Mada.

Ohanyan, A. (2012). Network Institutionalism and NGO Studies. International Studies Perspectives, 13(4), 366-389. 
Ostrom, E. (1982). Strategies of Political Inquiry. London: SAGE Publication Ltd.

Othman, S., Darus, F., \& Arshad, R. (2011). The influence of coercive isomorphism on corporate social responsibility reporting and reputation. Social Responsibility Journal, 7(1), 118-135.

Perreault, W. D., \& McCarthy, E. J. (2006). Essentials of Marketing: A GlobalManagerial Approach. New York: McGrawHill.

Peters, B. G. (2019). Institutional theory in political science: The new institutionalism. Northampton: Edward Elgar Publishing.

Pope, S., Bromley, P., Lim, A., \& Meyer, J. W. (2018). The Pyramid of Nonprofit Responsibility: The Institutionalization of Organizational Responsibility Across Sectors. Voluntas, 29, 1300-1314.

Pope, S., \& Meyer, J. W. (2015). The Global Corporate Organization. Management and Organization Review, 11(2), 173-177.

Puskarina, C., Asiah, M., \& Madung, O. G. (2015).
Mendemokratisasikan Kesejahteraan: Mengelola Akses, Strategi, dan Kapasitas Kontrol Politik. In C. Puskarina, M. Asiah, \& O. G. Madung (Eds.), Berebut Kontrol Kesejahteraan: Kasus-kasus Politisasi Demokrasi di Tingkat Lokal (pp. 2-34). Yogyakarta: Penerbit PolGov.

Radaelli, C. M., Dente, B., \& Dossi, S. (2012). Recasting Institutionalism: Institutional Analysis and Public Policy. European Political Science, 11, 537-550.

Susetiawan. (2012). Implementasi CSR dalam Arena Civil Society: Antara Idealisme dan Realitas. In Susetiawan (Ed.), Corporate Social Responsibility: Komitmen untuk Pemberdayaan Masyarakat (pp. 3-30). Sleman: Azzagrafika.

Zuhro, R. S. (2009). Demokrasi Lokal: Perubahan dan Kesinambungan Nilai-Nilai Budaya Politik Lokal di Jawa Timur, Sumatera Barat, Sulawesi Selatan dan Bali. Yogyakarta: Penerbit Ombak.

Zulkarnain, W. (2013). Dinamika Kelompok. Jakarta: Bumi. 